\section{How green is Japan}

\section{Tokyo}

AT A conference in Tokyo last week, the heads of the World Bank, the United Nations Environment Programme (UNEP) and the World Meteorological Organization (WMO) lavished praise on Japan for its contributions to the protection of the global environment. But in a series of independent meetings in Tokyo and elsewhere, representatives of nongovernmental organizations (NGOs) from all over the world severely criticized Japan for assisting the destruction of the environment in developing nations.

The conference on the Global Environment and Human Response toward Sustainable Development, sponsored by the Japanese government and UNEP, was proposed last year by then Prime Minister Noboru Takeshita. But unlike a similar event organized by UK Prime Minister Margaret Thatcher earlier this year, the Tokyo conference excluded the public as well as NGOs, some of which then organized rival meetings in Tokyo, Kyoto and Osaka.

The government-sponsored conference was the forum for a string of laudatory addresses. Barber B. Conable, president of the World Bank, praised Japan's endorsement of anti-pollution policies, its development of energy-efficient technology and its decision to emphasize environmental activities in its international development assistance programmes as "salutary examples" of how an industrial nation can adapt its policies to meet environmental challenge.

In the same vein, Godwin Oli Patrick Obasi, Secretary-General of the WMO, expressed the world community's "debt of gratitude" to the Japanese government for its agreement, three days earlier, to establish the WMO World Data Centre for Greenhouse Gases in Tokyo. And Mostafa Tolba, Executive Director of UNEP, praised Japan for its "visionary and generous leadership" in providing $\$ 2.3$ thousand million in Overseas Development Aid (ODA) for protection of the environment in developing countries.

Prime Minister Toshiki Kaifu mentioned Japan's intention to "increase" environmental overseas aid to approximately $\$ 2.25$ thousand million ( $¥ 300,000$ million) for the next three years, a commitment made by former Prime Minister Sousuke Uno at the Paris summit in July.

But this figure does not in fact represent an increase in spending. In 1988, environmental ODA commitments on a bilateral basis totalled about $¥ 110,000$ million. And the consequences of Japanese ODA formed one of the main targets of criticism by environmentalists at the NGO conferences.

Martin Kohr from Friends of the Earth in Malaysia, a speaker at an International People's Forum in Tokyo, said that Japanese ODA has been used to finance the building of logging roads in Sarawak where tropical rain forests are being rapidly depleted by Japanese-backed logging activities. And many other participants from South-East Asia complained that Japanese aid is often tied to Japanese commercial interests, and is environmentally destructive.

At the same conference, Bruce Rich of the Washington-based Environmental Defense Fund criticized Japan's representative at the World Bank for failing to speak out on environmental issues. Although the World Bank has in recent years taken a more active concern for the environment, said Rich, Japan's director of the bank has been "noticeable by his silence" on controversial projects named by the World Bank such as the power sector loan for hydroelectric dams in the Amazon in Brazil and the Sardor Sarovar Dam in Western India.

Rich, Kohr and several other environmentalists, including an Amazonian Indian, Paulino Paiakan, chief of the Kayapo Indians, were able to express their criticisms of Japan in a two-hour meeting with members of the Diet.

But several Diet members left halfway through the meeting and those who remained were given only five minutes to respond to the criticisms. Eimatsu Takakuwa, member of the House of Councillors, complained that he has been trying without success to persuade the Diet to introduce a law requiring environmental impact assessment of ODA projects.

Japan, the world's largest importer of tropical timber, seems unlikely to change its policy towards Sarawak. Taizo Watanabe, a spokesman for the Foreign Ministry, was reported in Japanese newspapers last week as saying that Japan has no intention of reducing or limiting imports of tropical wood.

Watanabe cited a UNEP report which says that Japan's imports account for only 2 per cent of the wood cut in Asia. But the figure is misleading: quoting the same report, Japan's Environment Agency says in its 1988 White Paper that, while migrating landless farmers and agricultural cultivation account for most of the tropical rain-forest destruction in Asia as a whole, in insular South-East Asia (Malaysia, Indonesia, Philippines and Papua New Guinea), commercial logging is "the chief culprit of degradation and indirect cause of deforestation".

In Sarawak alone, according to Kohr, commercial logging destroys about 300,000 hectares of primary forest each year while slash-and-burn for agriculture results in a loss of only 9,000 to 16,000 hectares. Nearly all of Sarawak's log exports go to Japan. David Swinbanks WORLD HEALTH

\title{
Health for all by year 2000?
}

\section{Parls}

Representatives of the 32 member states of the European region of the World Health Organisation (WHO) met in Paris last week to reconsider how to achieve their common aim of "health for all by the year 2000 ". Five years into the programme, member states have another ten years to achieve their 38 goals, ranging from adequate housing and clean water to health provision and research.

The European programme follows a 1977 WHO decision to orient its policies towards health rather than illness. The idea of health for all by 2000 "is not just a slogan" says a WHO communique. Sixtyfive health indicators have been agreed by member states to allow quantitative monitoring and comparisons within Europe every four years. "This", says Jo Asvall, director of the European region of WHO, "changes the reality of health".

The idea of health for all was agreed in 1978 and the 38-point strategy was adopted in 1984. By the year 2000 , WHO wants to see mean life-expectancy at birth increase by ten per cent to 75 years, to reduce infant mortality, and to eliminate measles, poliomyelitis, newborn tetanus, diptheria, congenital syphilis and indigineous malaria.

Other aims are to reduce the frequency of deaths from road accidents, heart disease, cancers and suicides, especially among the young. Some of the goals are closer at hand. By 1990, WHO wants Europe to have "sufficent supplies" of drinking water and, by 1995 , to have made "considerable progress" in the campaign against smoking.

But a new report* on the state of health in France suggests that this latter goal may be hard to achieve. Although mean life expectancy in France is now increasing by four months every year, the number of deaths from smoking-related illnesses is increasing and an estimated one in five males smoke more than 20 cigarettes a day.

The increase in life expectancy means that the proportion of the elderly in the population is increasing. In France, there will be an estimated 1.2 million elderly (over 85 years) by 2000 .

Peter Coles

* La santé en France - faits majeurs et grandes tendances. Published by $\mathrm{La}$ Documentation francaise, September 1989 